\title{
Correlation of Geochemistry of Gas between Fluid Inclusions and Reservoir
}

\author{
LI RONGXI* ZHAO BANGSHENG AHMED \\ KHALED
}

School of Earth Sciences \& Resources, Chang'an University, Xi'an, China, 710054(*correspondence: rongxi99@163.com)

\section{Sample and Method}

Samples were collected from the Middle Ordovician dolomite gas bed in a drilling hole in the Ordos basin, China. Plentiful primary gas inclusions were found in dolomite with a special shape of rhombus as dolomite. Gas/liquid ratio of gas fluid inclusions is over $90 \%$ with dark gray babble in the centre while coreless liquid circled around (Fig.1a). Composition of gas of fluid inclusion was measured by spectroscopy and isotope of fluid inclusion was detected using bulk analysis by crushing samples to liberate fluids. Composition of gas fluid inclusions was correlated with gas from reservoir.

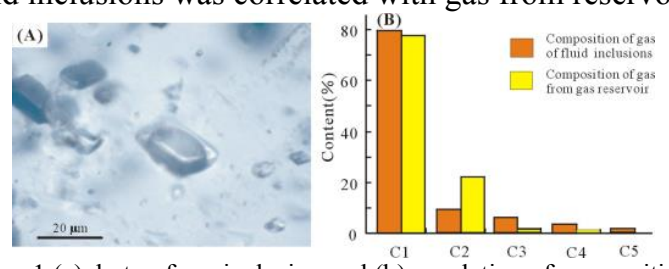

Figure.1 (a)photo of gas inclusion and (b)correlation of composition

\section{Results and Discussion}

Temperature measurements to fluid inclusions reveal typical oilfield brine of $\mathrm{CaCl}_{2}-\mathrm{NaCl}-\mathrm{H}_{2} \mathrm{O}$ system with salinity of 13.99 (wt) $\mathrm{NaCl} \%$. Compositions of saturated hydrocarbon gas of fluid inclusion are well correlated with that of gas from reservoir (Fig.1b). $\delta^{13} C_{1}$ is $33.35 \%$ while $\delta \mathrm{D}_{\text {SMOw }}$ is $-111.03 \%$, which are very close to that of gas from the Ordovician reservoir but much different from that of the Upper Paleozoic reservoir in the Ordos basin. Isotopes of gas fluid inclusion indicate the pyrolytic gas which formed from alginate or sapropel of marine carbonate rather than the Upper Paleozoic coal seam. The research indicates that composition of gas inclusion can be well correlated with that of gas reservoir. 